\title{
Combining ability studies for yield, associated traits and quality attributes in rice for South Gujarat (Oryza sativa $\mathrm{L}$.)
}

\author{
Navin Chander Gahtyari ${ }^{*}$, P. I. Patel $^{2}$, Rakesh Choudhary ${ }^{1}$, Sudhir Kumar ${ }^{3}$, Naveen \\ Kumar $^{4}$ and J. P. Jaiswal ${ }^{1}$ \\ ${ }^{1}$ Department of Genetics and Plant Breeding, G.B. Pant University of Agriculture and Technology, Pantnagar - \\ 263145 (Uttarakhand), INDIA \\ ${ }^{2}$ Department of Genetics and Plant Breeding, Navsari Agricultural University, Navsari - 396450 (Gujarat), INDIA \\ ${ }^{3}$ ICAR Research Complex for NEH Region Manipur Centre Lamphelpat, Imphal-795004, INDIA \\ ${ }^{4}$ Department of Molecular Biology and Genetic Engineering, G.B. Pant University of Agriculture and Technology, \\ Pantnagar - 263145 (Uttarakhand), INDIA \\ "Corresponding author. E-mail: navinnau.pbg@gmail.com
}

Received: May 1, 2016; Revised received: September 27, 2016; Accepted: January 8, 2017

\begin{abstract}
Line $x$ tester analysis using a set of four females, ten males and their forty hybrids was carried out to estimate the general combining ability of parents and specific combining ability of hybrids for yield and ten other associated components in rice (Oryza sativa L.) in a Randomized Block Design during Kharif 2011. GCA variances for females $\left(\mathrm{s}^{2} \mathrm{f}\right)$ were significant at $0.1 \%$ level of significance for plant height (40.8), no. of grains per panicle (505.9), grain yield per plant (29.1), test weight(17.9), straw yield per plant (61.3) and kernel L/B ratio (0.2) whereas specific combining ability (SCA) variances for $\mathrm{f} x \mathrm{~m}$ interactions were highly significant for all the characters. Non-additive gene action was prevalent in all characters (Range: 0.03 in amylose content to 0.88 in kernel length breadth ratio) except plant height (1.33) as evident by low GCA to SCA ratio. None of the parents were good general combiner for all traits, however, female IR-28 and male AMT-119 and PNR-546 were good general combiners for a maximum number of traits i.e. five traits out of eleven.. The general combining ability for grain yield per plant for female parent Gurjari (6.19) and NVSR-178 (5.29); and male parents AMT 119 (2.73) and PNR 546 (2.44) makes them a good choice for improving yields in a hybridization programme as these female and male parents are also having significant GCA effects for maximum number of yield associated traits i.e. four and five traits out of eleven for female and male parents respectively. A vis-à-vis comparison of top three specific combining ability crosses with their mean performance showed correlation and these crosses were having at least one good general combining ability parent.
\end{abstract}

Keywords: Females, GCA effects, Gene effect, Males, SCA effects

\section{INTRODUCTION}

Rice is the third most cultivated crop in terms of area and second most abundant in terms of production in the world. It's an important cereal along with maize and wheat and grown in an area of 163.25 million hectares with 740.96 million tonnes of production (FAO, 2014). In India, rice is cultivated in an area of 43.42 million hectares with 98.95 million tonnes production and average productivity of 2.28 tonnes per hectare (average of 2008-09 to 2012-13). The average productivity of India and Gujarat is way below the world average of 3.92 tonnes per hectare (Anonymous, 2014), thus making it a necessity to take yield enhancement measures.

Hybridization is a method to assemble the useful traits into a single cultivar and to exploit the phenomenon of heterosis. Identification of good parents for crossing programme and selection of superior hybrids from a crossing programme is the foremost concern of a plant breeder. Combining ability analysis helps in the evaluation of lines in terms of their genetic value and the selection of suitable parents for hybridization. It also helps in the identification of superior cross combinations. Estimation of combining ability requires generation of half-sib and full-sib progenies in a line $\mathrm{x}$ tester mating design, where variation among the half-sib families and full sib families provides an estimate of additive genetic variance (GCA) and non-additive gene action (SCA), respectively (Hallauer et. al., 2010).

The breeding for pure lines is advantageous when a major portion of variability is due to additive genetic variance, whereas breeding for hybrids would be advantageous when a major portion of variability is due to non-additive genetic variance (Hallauer et. al., 2010). Keeping these points in view, the present investigation was undertaken to estimate general combining ability of parents and specific combining ability of 
hybids for yield and yield attributing characters of rice through line $\mathrm{x}$ tester analysis in South Gujarat conditions.

\section{MATERIALS AND METHODS}

A line $\mathrm{x}$ tester mating design was undertaken at paddy research station, National Agricultural Research Project farm, Navsari Agricultural University, Navsari, during Rabi 2010. The lines were 4 female parents viz. Gurjari, IR-28, NVSR-178 and IET-19347 and testers were 10 male parents viz. AMT-119, AMT-209, AMT301, GAR-1, PB-1, PB-1460, PNR-546, Pusa-677, Pusa-834 and Sugandha-5. Each of the female parents was emasculated and pollinated with 10 male parents and thus 40 hybrids are obtained. All hybrids and selfed parental line seed was harvested, cleaned and used for sowing in the next season of Kharif 2011.

During Kharif 2011, each of the 54 entries (4 lines, 10 testers and 40 hybrids) was planted in a randomized block design with three replications. A single entry of each replication was consisted of a single row of 10 plants with a spacing $20 \times 15 \mathrm{~cm}$. Five competitive plants were randomly selected from each replication to record the observations on eleven characters viz. days to $50 \%$ flowering, no. of effective panicles per plant, panicle length $(\mathrm{cm})$, plant height $(\mathrm{cm})$, no. of filled grains per panicle, grain yield per plant $(\mathrm{g})$, test weight (g), amylose content $(\%)$, protein content $(\%)$, straw yield per plant $(\mathrm{g})$ and length breadth ratio. Seven traits $v i z$. days to $50 \%$ flowering, no. of effective panicles per plant, panicle length $(\mathrm{cm})$, plant height $(\mathrm{cm})$, no. of filled grains per panicle, grain yield per plant $(\mathrm{g})$ and straw yield per plant $(\mathrm{g})$ were taken in field condition. Rest four traits viz. test weight, amylose content, protein content and length breadth ratio was taken in laboratory. Test weight was taken from 1000 grains and weighed in grams. The amylose content was estimated as per the simplified colorimetric procedure of Juliano (1971). The nitrogen content was estimated from each sample by micro Kjeldahl method and percentage of protein was calculated by multiplying the nitrogen content percentage with factor 5.95 (Stoskopf, 1985). The kernel length: kernel breadth ratio was counted as kernel $\mathrm{L} / \mathrm{B}$ ratio $=$ Kernel length $(\mathrm{mm}) /$ Kernel breadth $(\mathrm{mm})$. Mean values over five plants for these eleven traits were subjected to statistical analysis for estimation of general combining ability (GCA) of parents and Specific combining ability (SCA) of crosses using INDOSTAT software, based on method by Singh and Choudhary (1985).

\section{RESULTS AND DISCUSSION}

The analysis of variance for combining ability (Table 1) revealed that general combining ability (GCA) variances for females $\left(\mathrm{s}^{2} \mathrm{f}\right)$ were significant for plant height, no. of grains per panicle, grain yield per plant, test weight, straw yield per plant and kernel L/B ratio. On the other hand, specific combining ability (SCA) variances for $\mathrm{f} x \mathrm{~m}$ interactions were highly significant for all the characters. Significance of female parent was previously reported for plant height (Prajapati and Mistry, 2014; Pradhan and Singh, 2008), days to 50\% flowering, no. of effective panicles per plant, panicle length, test wt., grain yield per plant and Dry matter (Pradhan and Singh, 2008). Similarly, female x male interaction was found significant for no. of grains per panicle, panicle length, test weight, grain yield per plant, Dry matter, protein content (Prajapati and Mistry, 2014; Pradhan and Singh, 2008), Plant height, days to $50 \%$ flowering, no. of effective panicles per plant (Pradhan and Singh, 2008). However, days to 50\% flowering and plant height have also been reported with insignificant female $\mathrm{x}$ male interaction (Prajapati and Mistry, 2014).

The magnitude of GCA variances was lower than SCA variances for all the characters except plant height indicating the predominance of non-additive gene action. However, the trait plant height seems to be governed by additive gene action. Significant GCA and SCA variances were also reported for days to $50 \%$ flowering, plant height, panicle length, length breadth ratio, protein content (\%), amylose content (\%) (Patil et. al., 2012), biomass per plant, harvest index (Kumar et al., 2007), number of productive tillers per plant, number of filled grains per panicle, test weight, grain yield per plant (Patil et. al., 2012; Kumar et al., 2007).

Lower magnitude of GCA variances as compared to SCA variances were also reported for days to $50 \%$ flowering, no. of filled grains per panicle, no.of effective panicles per plant (Sharma and Mani, 2008; Pradhan and Singh, 2008; Patil et. al. 2012), plant height, panicle length, test weight, grain yield per plant, dry matter (Pradhan and singh, 2008; Patil et. al., 2012). However higher magnitude of GCA variances as compared to SCA variances was reported for plant height and days to $50 \%$ flowering (Prajapati and Mistry, 2014), panicle length, grain yield per plant (Sharma and Mani, 2008), length breadth ratio, protein content (Patil et. al., 2012). Thus, the study by previous researchers and the current study is clearly signifying that the mode of gene action of yield and associated traits in rice that whether they are governed by additive or non-additive gene action keeps on changing with the change of parental lines.

General combining ability of parents and specific combining ability of hybrids were computed (Table 2 and Table 3 ). In case of rice, early maturing, short stature hybrids are desirable as they can withstand lodging, more responsive to fertilizers and can fit well into more numbers of crops per year. For days to $50 \%$ flowering IR-28 (-4.65) and Sugandha-5 (-4.87) were the female and male respectively with highest negative 
Navin Chander Gahtyari et al. / J. Appl. \& Nat. Sci. 9 (1): 60 - 67 (2017)

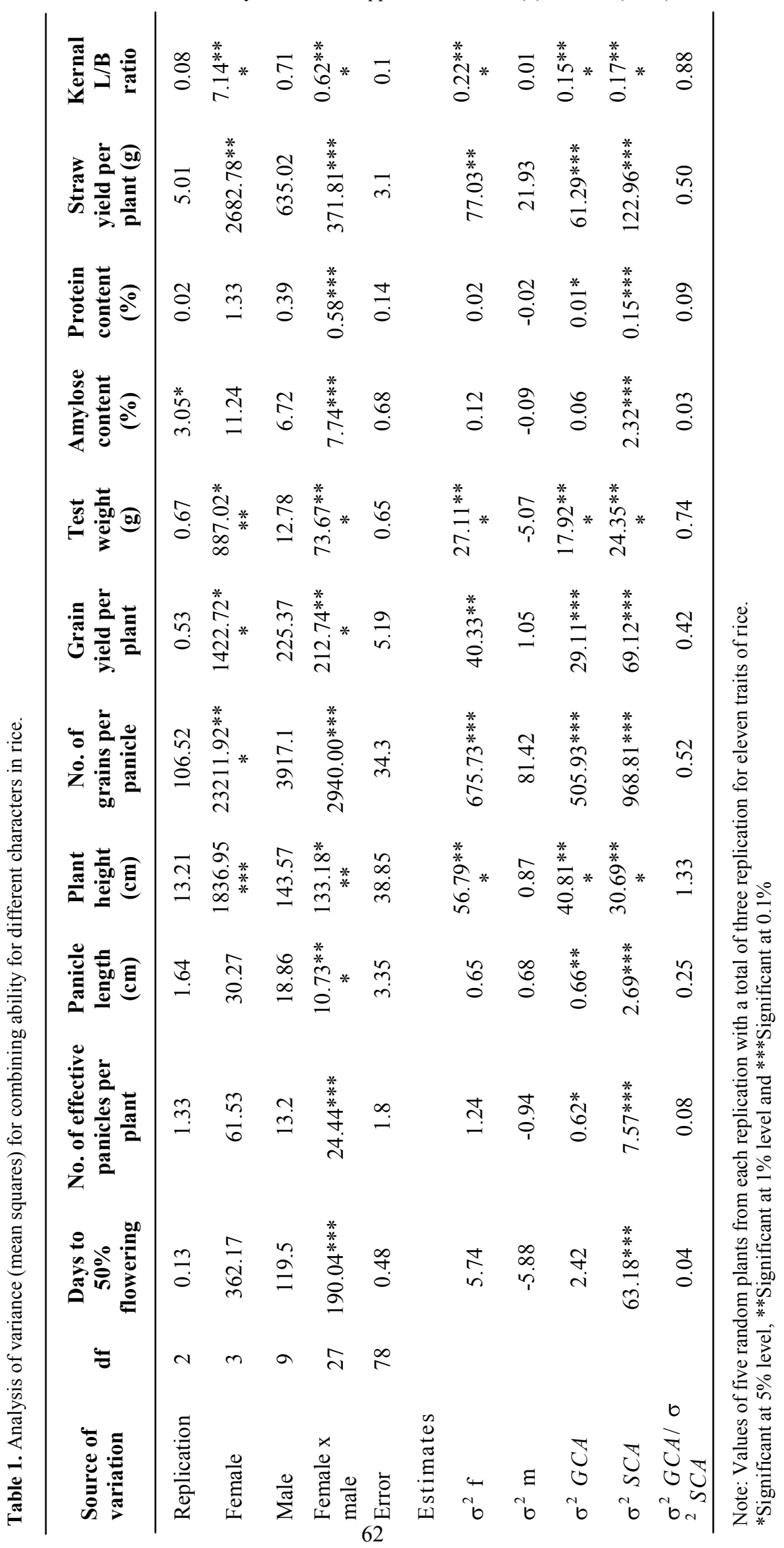




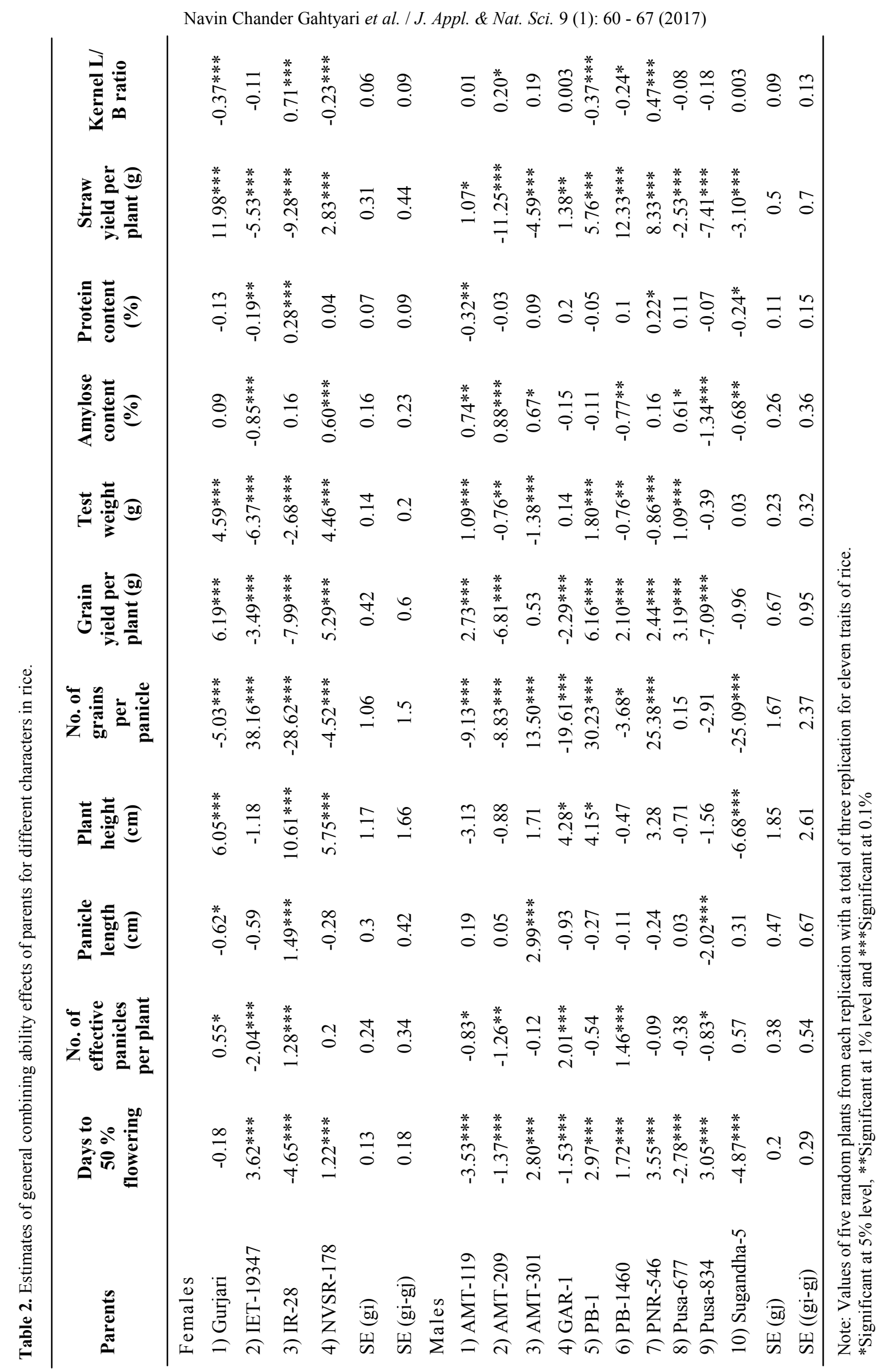




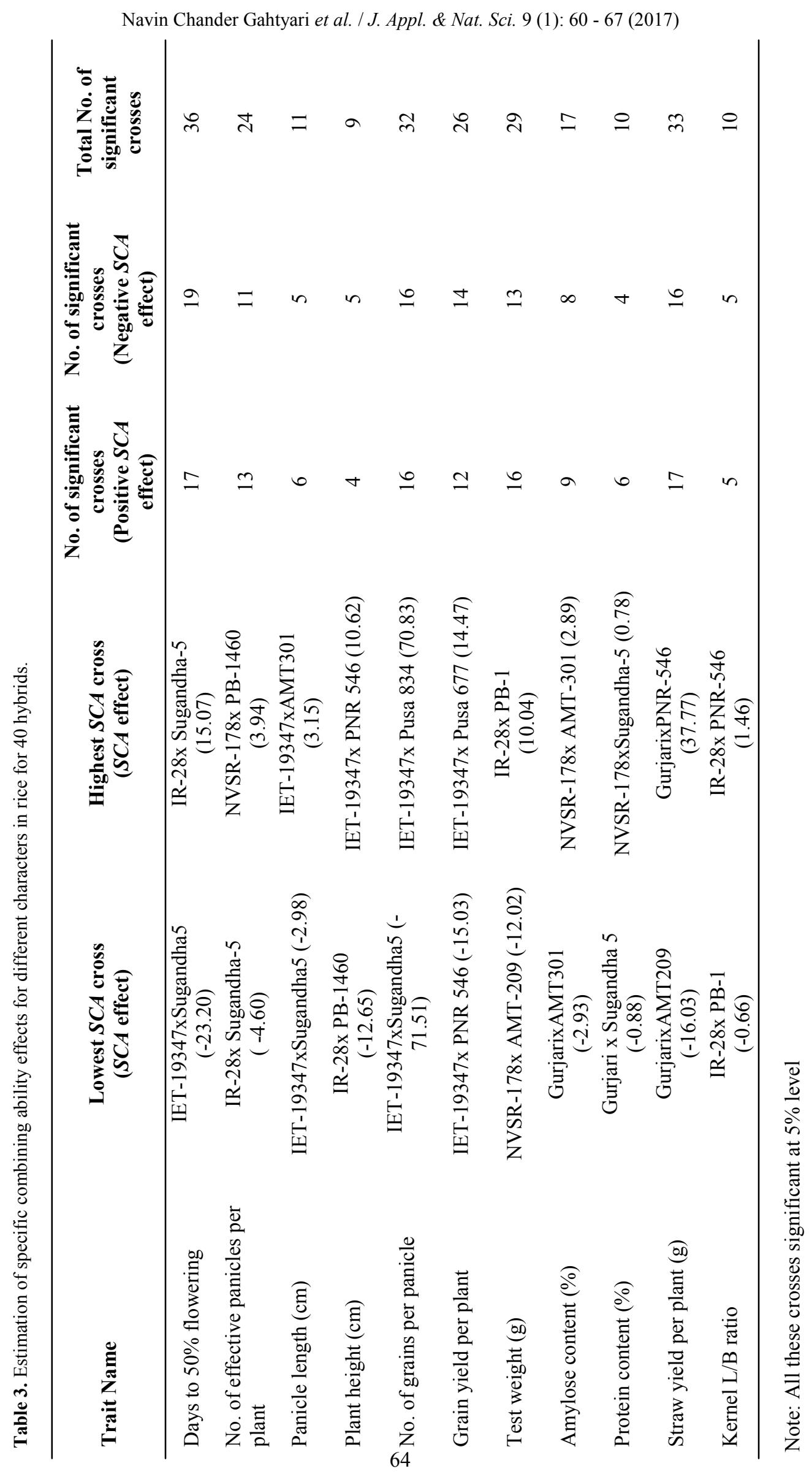


GCA effect. SCA effects ranged from -23.20 (IET19347 x Sugandha-5) to 15.07 (IR-28 x Sugandha-5). For plant height IR-28 (-10.61) and Sugandha-5 (6.68) were the female and male respectively with highest negative GCA effect. SCA effects ranged from 12.65 (IR-28 x PB-1460) to 10.62 (IET-19347 x PNR546).

Number of effective panicles per plant and panicle length is positively correlated with yield and hence significant positive GCA and SCA effects are highly desirable. In males GAR-1 (2.01) showed highest GCA effect and found to be good general combiner, while in females, IR-28 (1.28) showed significant positive GCA effect. Cross combination NVSR-178 x PB1460 (3.94) exhibited the maximum positive SCA effects. For panicle length IR-28 (1.49) and AMT-301 (2.99) were the female and male respectively with highest significant positive GCA effect. IET-19347 x AMT-301 (3.15) was the hybrid with highest SCA effect among six hybrids showing significant positive SCA effect.

Number of grains per panicle is an important component contributing towards higher grain yield. For this trait, one female (IET-19347) and three males (PB-1, PNR-546 and AMT-301) exhibited significant positive GCA effects in desirable direction. As regard to SCA effects of crosses, sixteen hybrids showed significant positive SCA effects with cross combination IET19347 x Pusa-834 (70.83) exhibiting the maximum significant positive SCA effect. (Tables 2,3).

Grain yield per plant is a very important trait as yield is sum total of all the direct and indirect effects affecting productivity. A total of 7 parental lines with 2 females and 5 males showed positive significant GCA effects. Gurjari (6.19) and PB-1 (6.16) were the topmost female and male respectively, with highest significant positive GCA effect. Estimation of SCA effects ranged from -15.03 (IET-19347 x PNR-546) to 14.47 (IET-19347 x Pusa-677). For test weight, out of 5 parental lines having significantly positive GCA value, Gurjari (4.59) and PB-1 (1.80) were the top general combining female and male respectively. SCA effects of hybrids varied from -12.02 (NVSR-178 x AMT209) to 10.04 (IR-28 x PB-1).

SCA effects ranged from -2.93 (Gurjari x AMT-301) to 2.89 (NVSR-178 x AMT-301) for amylose content. Nine crosses showed significant positive SCA effects with cross, NVSR-178 x AMT-301 (2.89) exhibiting maximum significant SCA effect followed by IET19347 x PB-1460 (2.39) and IET-19347 x Sugandha-5 (2.25). NVSR-178 (0.60) and AMT-209 (0.88) were the topmost female and male respectively, with highest significant positive GCA effect.

The GCA effects for protein content in parents revealed that only two parents i.e female parent IR-28 $(0.28)$ and male parent PNR-546 (0.22) have positive significant GCA effect. SCA effects varied from -0.88
(Gurjari $\mathrm{x}$ Sugandha-5) to 0.78 (NVSR-178 $\mathrm{x}$ Sugandha-5). A total of six hybrids showed positive and four showed negative significant SCA effects.

A total of 7 parental lines with 2 females and 5 males showed positive significant GCA effects for straw yield per plant. Gurjari (11.98) and PB-1460 (12.33) was the best general combining female and male respectively. Range of SCA effects varied from -16.03 (Gurjari x AMT-209) to 37.77 (Gurjari x PNR-546).

Only one female viz. IR-28 and three males viz. PNR546, AMT-209 and AMT-301 showed significant positive GCA effects for L/B ratio. Estimation of SCA effects ranged from -0.66 (IR-28 x PB-1) to 1.46 (IR$28 \times$ PNR-546). The cross, IR-28 x PNR-546 (1.46) exhibited maximum SCA effect followed by NVSR178 x PB-1 (0.61) and IR-28 x AMT-301 (0.45).

In the present study, it was observed that none of the parents was good general combiner for all the traits. Among females, Gurjari and NVSR-178 were good general combiners for four out of eleven characters with grain yield per plant, test weight and straw yield per plant as the mutually inclusive traits among the two females. Among males PNR-546 and AMT-119 were good general combiners for maximum no. of traits viz. five out of eleven with grain yield per plant and straw yield per plant as the mutually inclusive traits among the two testers (Table 2). Several researchers have computed general combining ability of parents through diallel, partial diallel and line $\mathrm{x}$ tester and found that none of the parent was good general combiner for the entire studied yield and associated traits in rice. A study of 12 yield and associated traits on 13 parents (Pradhan and Singh, 2008), 8 yield and associated traits on 9 parents (Sharma and Mani, 2008), 16 yield and associated traits on 12 parents (Tyagi et al., 2008), 10 yield and associated traits on 10 parents (Patil et al., 2012) revealed that none of the parents were good general combiners for all the studied traits. The best general combining ability parent identified has desirable GCA effect for 10 yield and associated traits out of 12 (Pradhan and Singh, 2008), 6 yield and associated traits out of 8 (Sharma and Mani, 2008), 9 yield and associated traits out of 16 (Tyagi et al., 2008) and 7 yield and associated traits out of 10 (Patil et al., 2012).

In case of specific combining ability effects, none of the hybrids exhibited favorable SCA effect for all the characters. In the present study, positive specific combining ability is desirable for all the characters except days to $50 \%$ flowering and plant height. Significant specific combining ability effect in favorable direction were observed in many crosses for days to $50 \%$ flowering (19), no. of effective panicles per plant (13), panicle length (6), plant height (5), no. of grains per panicle (16), grain yield per plant (12), test weight (16), amylose content (9), protein content (6), straw yield per plant (17) and kernel L/B ratio (5) (Table 3). Days 
Table 4. A summary table showing the top three specific combination along with the $G C A$ effects of the parents and their per se performance.

\begin{tabular}{|c|c|c|c|c|c|}
\hline Characters & Best specific combination & $\begin{array}{c}S C A \\
\text { effects }\end{array}$ & $\begin{array}{c}\text { Perse } \\
\text { performance }\end{array}$ & $\begin{array}{l}\text { Rank out of } 40 \\
\text { hybrids based } \\
\text { on Per se } \\
\text { performance }\end{array}$ & $\begin{array}{c}G C A \text { effects of } \\
\text { the parents } \\
\text { involved }\end{array}$ \\
\hline \multirow{3}{*}{$\begin{array}{l}\text { Days to } 50 \% \\
\text { flowering }\end{array}$} & IET-19347xSugandha5 & -23.20 & 62.33 & 1 & $\mathrm{PXG}$ \\
\hline & IET-19347xAMT209 & -9.03 & 80.00 & 7 & $P \times G$ \\
\hline & NVSR-178x PB-1 & -7.63 & 83.33 & 12 & PX P \\
\hline \multirow{3}{*}{$\begin{array}{l}\text { No. of effective } \\
\text { panicles per } \\
\text { plant }\end{array}$} & NVSR-178x PB-1460 & 3.94 & 16.47 & 2 & $\mathrm{~A} \times \mathrm{G}$ \\
\hline & GurjarixPNR-546 & 3.65 & 14.98 & 4 & $\mathrm{GX} A$ \\
\hline & IET-19347xSugandha5 & 3.60 & 13.00 & 10 & $\mathrm{~A} X \mathrm{~A}$ \\
\hline \multirow{3}{*}{$\begin{array}{l}\text { Panicle length } \\
\text { (cm) }\end{array}$} & IET-19347xAMT301 & 3.15 & 30.48 & 1 & $\mathrm{~A} \times \mathrm{G}$ \\
\hline & NVSR-178x AMT-119 & 2.45 & 27.29 & 6 & $\mathrm{~A} X \mathrm{~A}$ \\
\hline & NVSR-178x PB-1 & 2.41 & 26.79 & 8 & A X A \\
\hline \multirow{3}{*}{$\begin{array}{l}\text { Plant height } \\
(\mathrm{cm})\end{array}$} & IR-28x PB-1460 & -12.65 & 65.53 & 1 & GX A \\
\hline & IET-19347x PB 1 & -9.70 & 82.53 & 8 & A X P \\
\hline & NVSR-178x AMT-119 & -8.88 & 83.00 & 10 & P X A \\
\hline \multirow{3}{*}{$\begin{array}{l}\text { No. of grains } \\
\text { per panicle }\end{array}$} & IET-19347x Pusa 834 & 70.83 & 230.80 & 1 & GX A \\
\hline & IR-28x Sugandha-5 & 49.20 & 120.20 & 21 & PX P \\
\hline & IET-19347x Pusa 677 & 33.45 & 196.47 & 4 & $\mathrm{G} \times \mathrm{A}$ \\
\hline \multirow{3}{*}{$\begin{array}{l}\text { Grain yield per } \\
\text { plant }(\mathrm{g})\end{array}$} & IET-19347x Pusa 677 & 14.47 & 41.85 & 6 & $P \times G$ \\
\hline & GurjarixPNR-546 & 13.13 & 49.45 & 1 & GX G \\
\hline & NVSR-178x PB-1460 & 12.12 & 47.19 & 2 & GX G \\
\hline \multirow[t]{3}{*}{ Test weight (g) } & IR-28x PB-1 & 10.04 & 34.89 & 2 & PX G \\
\hline & NVSR-178x PNR-546 & 7.84 & 37.17 & 1 & G X P \\
\hline & IET-19347xAMT209 & 5.23 & 23.82 & 24 & PX P \\
\hline \multirow{3}{*}{$\begin{array}{l}\text { Amylose con- } \\
\text { tent (\%) }\end{array}$} & NVSR-178 x AMT-301 & 2.89 & 25.36 & 1 & GX G \\
\hline & IET-19347 x PB-1460 & 2.39 & 21.97 & 12 & PX P \\
\hline & IET-19347 x Sugandha-5 & 2.25 & 21.91 & 13 & PX P \\
\hline \multirow{3}{*}{$\begin{array}{l}\text { Protein } \\
\text { content (\%) }\end{array}$} & NVSR-178 x Sugandha-5 & 0.78 & 6.89 & 5 & A X P \\
\hline & NVSR-178 x AMT-209 & 0.60 & 6.92 & 4 & $\mathrm{~A} X \mathrm{~A}$ \\
\hline & IR-28x PNR-546 & 0.50 & 7.31 & 1 & GX G \\
\hline \multirow{3}{*}{$\begin{array}{l}\text { Straw Yield per } \\
\text { plant }(\mathrm{g})\end{array}$} & GurjarixPNR-546 & 37.77 & 92.32 & 1 & GX G \\
\hline & IET-19347xAMT119 & 13.81 & 43.59 & 8 & P X G \\
\hline & IET-19347xAMT209 & 8.54 & 26.00 & 29 & PX P \\
\hline \multirow{3}{*}{$\begin{array}{l}\text { Kernel L/B } \\
\text { ratio }\end{array}$} & IR-28x PNR-546 & 1.46 & 6.29 & 1 & GX G \\
\hline & NVSR-178x PB-1 & 0.61 & 3.65 & 13 & PX P \\
\hline & IR-28x AMT-301 & 0.45 & 4.99 & 2 & GX A \\
\hline
\end{tabular}

$\mathbf{G}=$ Good parent having significant $G C A$ effects in desired direction; $\mathbf{A}=$ Average parent having either positive or negative but non-significant $G C A$ effects; $\mathbf{P}=$ Poor parent having $G C A$ effect in the undesired direction

to $50 \%$ flowering, no. of effective panicles per plant, panicle length, plant height, no. of filled grains per panicle, grain yield per plant, test weight, amylose content, protein content, straw yield per plant and length breadth ratio were the yield and associated traits studied by various researchers (Singh et al., 2007; Parihar and Pathak, 2008; Sharma and Mani, 2008; Tyagi et al., 2008; Prajapati and Mistry, 2014). None of the hybrid was having desirable SCA effect for all the studied yield and associated traits in rice was also reported by Singh et al. (2007) in 21 hybrids, Parihar and Pathak (2008) in 48 hybrids, Pradhan and Singh (2008) in 30 hybrids, Sharma and Mani (2008) in 18 hybrids and Prajapati and Mistry (2014) in 50 hybrids of rice.

A comparative study of top three crosses with highest 
specific combining ability was made (Table 4). For all the traits except no. of effective panicles per plant, topranked hybrid according to per se performance was also among the best three specific combining ability crosses. This clearly shows some degree of relationship between heterosis and specific combining ability effects. A closer look at the general combining ability of these crosses parentage revealed that at least one of the parent was a good general combiner. This clearly signifies the importance of computing general combining ability of parents and specific combining ability of hybrids. A closer look at the Parihar and Pathak (2008) and Pradhan and Singh (2008) work on 48 and 30 hybrids respectively, revealed that their top three hybrids for grain yield per plant trait in rice was made up of a cross which consists of atleast one parent having good general combining ability for grain yield per plant. The present investigation for nature of gene action, identification of superior parents for different yield and associated traits based on their GCA effect and finding superior hybrids based on their SCA effect were done on entirely new set of parental lines. The female parent chosen was prominent rice variety with specific adaptation to local conditions of South Gujarat. The choosen male parents were having aromatic behavior in grains along with good attributes of yield and associated traits. Hence, the good general combiner parents and top specific cross combinations for eleven yield and associated traits in the study can be exploited for improving these eleven traits and isolation of superior hybrids for South Gujarat conditions.

\section{Conclusion}

None of the parents were good general combiner for all traits, however, female IR-28 and male AMT-119 and PNR-546 were good general combiners for a maximum number of traits viz. 5 traits out of total 11. But since, grain yield per plant was the most important trait followed by other associated traits for improving total rice yields, female parent Gurjari and NVSR-178, and male parents AMT-119 and PNR-546 are the parents having maximum no. of yield attributing traits. Female parent Gurjari and NVSR-178 were good general combiner for 4 traits each including grain yield per plant viz. Gurjari for no. of effective panicles per plant (0.55), grain yield per plant (6.19), test weight (4.59) and straw yield per plant (11.98) and NVSR-178 for grain yield per plant (5.29), test weight (4.46), amylose content (0.60) and straw yield per plant (2.83).

Male parent AMT-119 and PNR-546 were good general combiners for 5 traits each including grain yield per plant. Whereas, AMT-119 was good general combiner for days to $50 \%$ flowering $(-3.53)$, grain yield per plant (2.73), test weight (1.09), amylose content (0.74) and straw yield per plant (1.07), PNR-546 was a good general combiner for no. of grains per panicle (25.38), grain yield per plant (2.44), protein content (0.22), straw yield per plant (8.33) and length breadth ratio (0.47).

Hence, in the present study, improvement of traits for developing high yielding varieties should be made by crossing IR-28, Sugandha-5, AMT-119 and Pusa-677 for earliness, Gurjari, NVSR-178, PB-1, AMT-119, PB -1460, Pusa-677 and PNR-546 for yield and yield contributing characters. There is a preponderance of non additive gene action for all traits except plant height as evident by low GCA to SCA ratio. This clearly suggest for an exploitation of heterosis breeding. However, plant height seems to be governed by additive gene action as indicated by the high magnitude of $\sigma^{2} 2 \mathrm{GCA} /$ $\sigma^{2} \mathrm{SCA}$ ratios. Hence, for improving plant height in terms of attaining short stature, effective selections has to be made generation after generations.

\section{REFERENCES}

Anonymous. (2014). Agriculture Statistic at a glance 2014 [Online]. Ministry of Agriculture, Government of India. $\mathrm{http} / / /$ eands.dacnet.nic.in/PDF/Agricultural-Statistics-At -Glance2014.pdf [1st Feburay, 2016].

FAO (2014). Food and Agriculture organization [Online]. http://faostat3.fao.org/download/Q/QC/E [1st Feburay, 2016].

Hallauer, A.R., Carena, M.J. and Filho, J.B.M., 3rd eds. (2010). Quantitative Genetics in Maize Breeding, Handbook of Plant Breeding, Springer, New York. 6: 663

Juliano, B.O. (1971). A simplified assay for milled rice amylose. Cereal Sci. Today. $16: 334-360$.

Kumar, S.; Singh, H. B. and Sharma, J. K. (2007). Combining ability analysis for grain yield and other associated traits in rice. Oryza, 44 (2): 108-114

Parihar, A. and Pathak, A. R. (2008). Combining ability and heterosis for yield and component traits in rice. Indian J. Crop Sci., 3 (1) : 169-171

Patil, P. P., Vashi, R. D., Lodam, V. A., Patil, S. R. and Patil, S. S. (2012). Combining ability for yield and component characters in rice (Oryza sativa L.). Agric. Sci. Digest, 32(1): 28-32

Pradhan, S. K. and Singh, S. (2008). Combining ability and gene action analysis for morphological and quality traits in basmati rice. Oryza, 45 (3): 193-197

Prajapati, M. B. and Mistry, P. M. (2014). Line x Tester analysis in Rice (Oryza sativa L.). BIOINFOLET, 11 (2C): 677-687

Sharma, R. K. and Mani, S. C. (2008). Analysis of gene action and combining ability for yield and its component characters in rice. Oryza, 45 (2) : 94-97

Singh, N. K.; Kumar, A. and Kumar, R. (2007). Combining ability for yield and yield components in rice. Oryza, 44 (2) : 156-159

Singh R. K. and Chaudhry B.D., eds., (1985). Biometrical methods in quantitative genetic analysis, Kalyani Publisher, New Delhi, pp.205-214.

Stoskopf, N. C. (1985). Cereals grain crops. Reston. Pub.Co.Verginia: 256-278

Tyagi, J. P.; Singh, T. and Singh, V. P. (2008). Combining ability analysis in rice. Oryza, 45 (3) : 235-238 